\title{
Nature's biological weapon
}

The 1918 flu pandemic killed 50 million people — and it could happen again.

\section{The Great Influenza: The Epic Story of the 1918 Pandemic by John M. Barry \\ Viking: 2004. 546 pp. $\$ 29.95$ \\ John Oxford}

In the modern world where a newly discovered virus has been called sin nombre, or 'nameless', to avoid pinpointing a geographical origin, a strange paradox has arisen several nations are claiming Spanish influenza as their own. But virologists are all agreed on one thing: the virus did not emerge in Spain. A strong US contingent insists that it arose in army camps of 60,000 soldiers in Kansas and then spread to Europe via troop ships. My own opinion is orientated towards the European Union: there was an initial focus in British army camps in France and Britain in 1916 and 1917, and then a gradual seeding over the next 12 months before the virus burst upon an unsuspecting world. So shall we rename this killer as the greatest US bioterrorist weapon of all times, or English or French? Of course not - the virus will always be known as the Spanish flu or, even worse, the Spanish Lady.

Two superb recent papers (S. J. Gamblin et al. Science 303, 1838-1842; 2004 and J.Stevens et al. 303, 1866-1870; 2004), which detail the X-ray crystallography of the major surface antigen of the 1918 virus, are full of descriptions of 'Spanish' influenza. I believe that from the gas-ridden, overcrowded trenches and nearby hospitals of already ruined Europe, filled with enough pigs, chickens and ducks to feed 2 million troops each day, arose a 10,000-nucleotide beast surrounded by a fragile lipid sphere. It seeded itself around the world while its biological clock ticked to ring at midnight on 11 November 1918, when it exploded worldwide.

In a world already shattered by death from high explosives, what more could possibly happen? The deaths of 50 million more innocents, from Spanish flu. The pictorial image is not far removed from Pieter Bruegel the Elder's Triumph of Death, with bubonic plague and the pale rider on a pale horse gathering in souls at random. I had not fully appreciated US President Woodrow Wilson's demand of the American nation once the decision had been made to go to war: "the spirit of ruthless brutality and deathless determination of total war". This almost totalitarian command led directly to an infectious-disease tragedy in the United States when the virus broke out in army camps and on troop ships to Europe.Wilson's

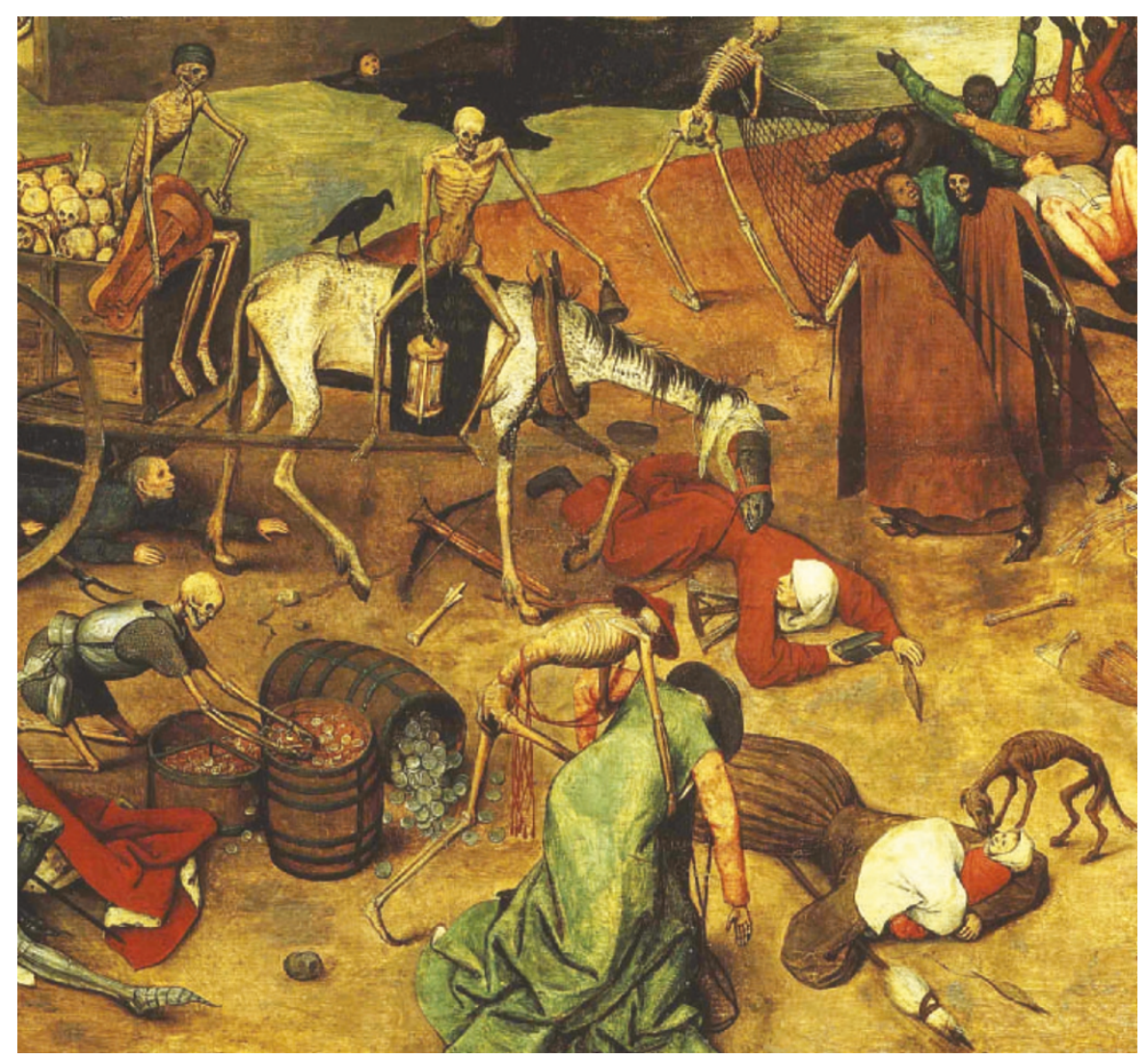

Death rides again: the 1918 flu pandemic caused scenes like those in Bruegel's The Triumph of Death.

government knew the risks but forced the troop movement onwards nevertheless.

This is the setting for John Barry's The Great Influenza. Barry is a philosopher who writes like an angel. Through a vision of the scientists of the day - Flexner, Welch and Avery - he brings back the tension and excitement, the despair and the sorrow. The only previous book that captured this was They Came Like Swallows, a 1937 book in which William Maxwell quietly and beautifully reconstructs his Edwardian childhood in Connecticut. His mother died of the flu and he was changed forever, never again feeling safe. But Barry's writing matches this while still managing to capture the science of virology. We read about viral swarms and quasi-species, passage from human to human to produce virulent viruses, reassortment and genetic recombination. A cytokine storm is so well described that I will borrow the phraseology to explain it to my own students. But this is not a textbook of influenza — that is its strength. The author knows his ground well and stays there.

Barry has made some serious decisions about the form and nature of his book and I, with one exception, agree wholeheartedly with him. There are no modern scientists here but our predecessors by two or three generations - virology is just emerging, from a world of chocolate agar plates, Bunsen burners and the Gram test. My single grouse is that book is almost entirely focused on the United States. A first reading so swept me along with the narrative that I overlooked this omission. But on a second look - and yes I have indulged myself and read the book twice - the uni-nationalist flavour slightly impedes the scientific story. Barry pulls information from everywhere, from recent TV films, newspapers of the times and scientific journals, and, to the best of my knowledge, it is accurate as it can be.

One of the virus's victims was William Osler, a member of the gang of four who founded Johns Hopkins School of Medicine in Baltimore. I never had much sympathy for Osler and his textbook, with its quotes about "pneumonia being the old man's friend". Here we read how he caught flu as a 70-year-old. In November 1919, in another wave of infection, he had "paroxysms of coughing", his pleural attachments were ripped to smithereens, and nearly a pint of pus was drained from lungs. For three months he struggled. He quoted Tennyson "of happy men that have the power to die", 
and on 29 December his wish was granted. He died of virus-induced pneumonia. How can this disease be anyone's friend? But this description of bronchopneumonia must have been more typical of the deaths in 1918 than the exaggerated tales of blood and gore. It was bad enough in it quietness, strangulation and breathlessness, and needs no exaggeration.

These post-1918 epidemic waves of flu last until 1922 or so, and then we encounter, albeit briefly, the outbreak of 'sleepy sickness', which immobilized another 5 million souls around the world.

Through page after page we relive that period and can ask ourselves whether it could happen again. Of course it could, and we are no better prepared to resist it. Influenza virologists know this, the World Health Organization knows it and so do publichealth specialists. But still we seem to be suspended as if in a dream, like Alice in Wonderland. There is fine talk of vaccines and antivirals, but if such a pandemic influenza A virus were to jump the species barrier this month, we could all be caught in a catastrophe as serious as that of 1918 .

This book is a wake-up call. It should reach beyond our small, incestuous coterie of a few hundred flu virologists into a far greater world that will not like what it sees. The theme here is that a new virus will come. We have the knowledge and the scientific means to blunt its virulence, but the attention of politicians and decision-makers has been diverted towards bioterrorism and war.

Should this timely book prove a turning point, then we could label Barry as a saviour, although it is clear that this was not his intention when writing the book. He totally immerses us in the 1918 flu battle. These first scientists challenged the natural order, and when the great influenza came they placed their lives in the path of the disease. The scientific knowledge that is still coming out of studies of the 1918 pandemic points us "to much that lies in medicine's future". The ordered, quiet world of Maxwell has vanished. But no amount of slick presentation or clever lawyers' talk from our leaders will escape this volcano sitting in all our countries.

Influenza was the twentieth century's weapon of mass destruction, killing more than the Nazis, more than the atomic bomb, and more than the First World War. We would do well to dwell very seriously indeed on this fact. Nature is the greatest bioterrorist of our world, and we should concentrate and expand our efforts in public health. Emerging viruses could do for us all, as easily and as quickly, or even more so, than the Great Influenza of 1918.

John Oxford is at Retroscreen Virology Limited, Centre for Infectious Diseases, Institute of Cell and Molecular Science, Queen Mary's School of Medicine and Dentistry, University of London, London E1 4NS, UK.

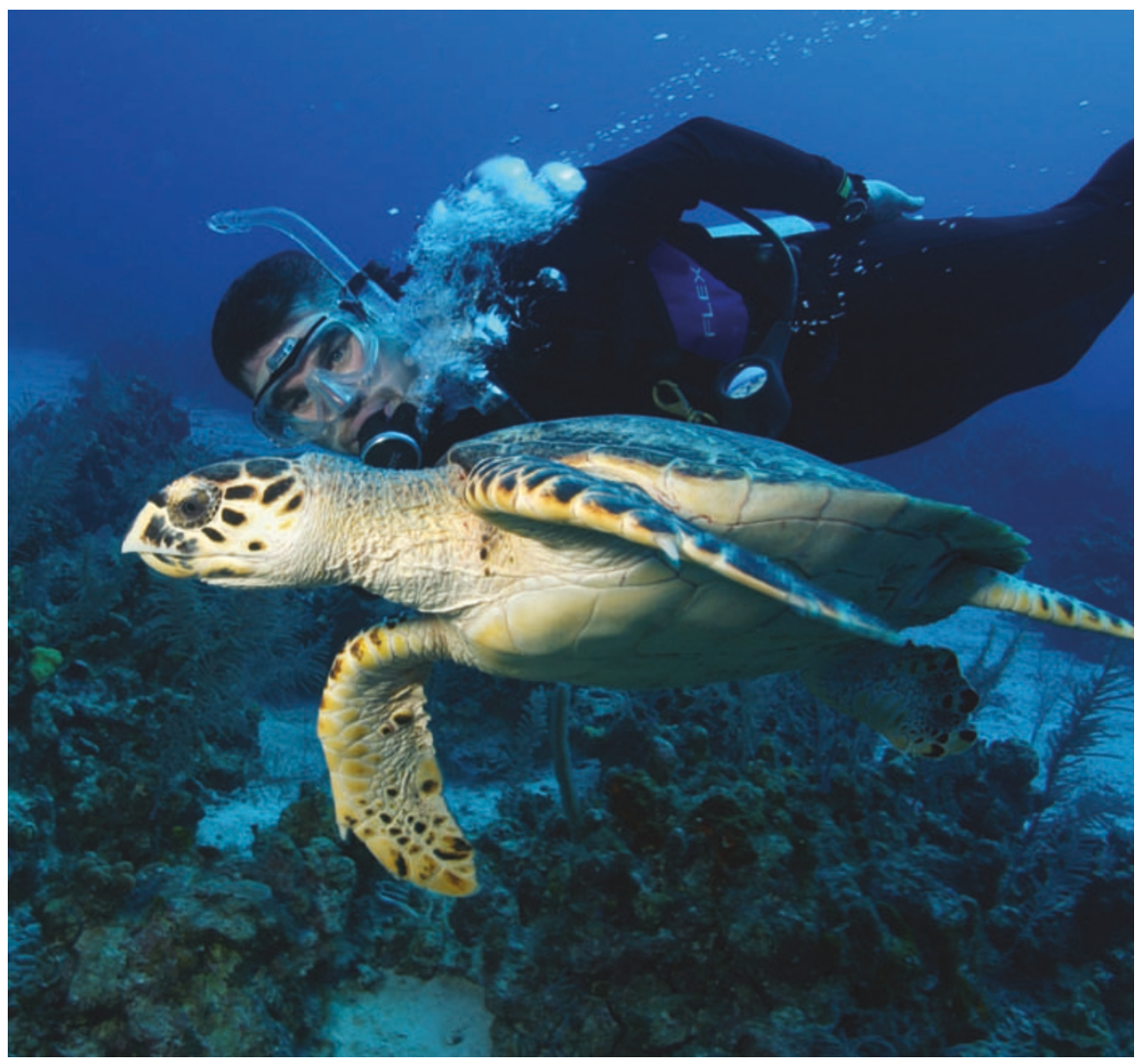

Deep trouble: turtles, once a common sight on Caribbean reefs, have been destroyed by hunting.

\section{Taking stock of conservation}

\section{Against Extinction: The Story of Conservation \\ by William M. Adams \\ Earthscan: 2004. 328 pp. $£ 55$ (hbk),

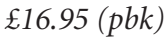

\section{E. J. Milner-Gulland}

I recently observed a UK delegate at a conference lecturing a representative of a developing country's wildlife ministry on how they should be doing conservation. The question under discussion was not the one that might have been asked a few decades ago - "What are you doing for the species?" - but rather, "What are you doing about rural poverty?"

Bill Adams' book Against Extinction encourages us to reflect on the continuities and upheavals in the way we do conservation. As Adams insightfully points out, most conservationists have three time-frames: the long term, for comparing extinction rates, for example; their lifetime, for nostalgia about paradise lost; and the immediate crisis, for most of their interventions. He wants us to look at conservation on another time-frame — the past century - to help us understand the route that led to our current conservation philosophies, and, in so doing, to reflect on our unwitting prejudices and assumptions.
Ignorance of recent history, described by Daniel Pauly as the "shifting baseline syndrome", is a pernicious and prevalent problem in conservation. J. B. C. Jackson has pointed out that current observations of Caribbean reefs are of an ecosystem that has already been fundamentally altered from its natural state by human intervention. Observers in the fifteenth century, before turtle populations were ravaged by hunting, described densities so high that it seemed ships might run aground on them. Jackson memorably described present-day Caribbean reef systems, which have few turtles, as being like the Serengeti without the ungulates. There are many examples in which our ignorance of human and ecological history clouds our understanding of contemporary events. So I applaud Adams' insistence that we look back to obtain a true perspective on the conservation movement today.

Adams' definition of conservation is narrow, and he makes it clear from the start that he is considering only the birth of conservation among Western colonial nations, starting around the middle of the nineteenth century. Central to the book is an organization now called Fauna and Flora International, which celebrated its centenary last year. It has led the way in Western conservation thinking throughout the past century, changing from its origins as an influential group of colonial hunters primarily focusing on game animals in Africa to its current role, working through local, non-governmental 